\title{
Demokrasi Indonesia dalam Lintasan Sejarah \\ Yang Nyata dan Yang Seharusnya \\ Oleh:
}

\author{
Dhani Kurniawan
}

\begin{abstract}
ABSTRAK
Demokrasi merupakan konsep pemerintahan yang bermula dari konsep yang dijalankan di polis Athena pada masa Yunani kuno. Konsep tersebut sempat terkubur lama tetapi kembali menemukan jalankan seiring berakhirnya abad pertengahan di Eropa. Demokrasi makin berkembang dan dianggap sebagai sistem yang paling baik. Ide demokrasi telah merasuk ke Indonesia sejak negeri masih menjadi negeri jajahan. Sekelompok kecil pemuda Indonesia yang menjadi saksi perkembangan demokrasi di Eropa mencuri ide demokrasi dan membawanya ke tanah air. Demokrasi kemudian terus mengalami pergumulan dengan cita-cita kemerdekaan. Setelah Indonesia merdeka pergumulan tersebut terus berlanjut. Demokrasi mencari bentuknya melalui jalan yang tidak mudah. Negeri ini mengalami percobaan-percobaan pelaksanaan demokrasi. Sistem demokrasi parlementer yang pada mulanya dianut akhirnya harus jatuh karena fragmentasi politik yang keras. Indonesia lalu menganut demokrasi terpimpin. Suatu konsep yang konon merupakan konsep asli Indonesia tetapi mendapat kritik keras dari banyak pihak dan salah satunya adalah mantan wakil presiden Mohammad Hatta. Demokrasi terpimpin ternyata ambruk bersama dengan tersingkirnya Sukarno. Lahirlah orde baru yang kemudian menganut demokrasi Pancasila. Pada prakteknya demokrasi Pancasila bahkan lebih sentralistik daripada demokrasi terpimpinnya Sukarno. Orde baru jatuh dan demokrasi terus berubah. Demokrasi politik secara prosedural berkembang pesat. Namun nyatanya demokrasi belum membawa hasil yang diharapkan. Masih banyak bolong di sana-sini. Dewasa ini pun diskusi tentang demokrasi masih terus berlanjut. Banyak jalan ditempuh banyak teori terus diimpor. Namun sayang tak banyak yang mengingat kritik dan konsepsi Hatta sebagai jalan untuk kembali menggali demokrasi Pancasila.

Kata Kunci
\end{abstract}

Ide, demokrasi, praktek, konsepsi Hatta,

\section{A. Suatu Keinsafan Pada Warisan Yunani}

Konsep awal demokrasi bisa kita lacak jauh pada peradaban Yunani kuno yang bercorak polis. Polis merupakan negara kota yang otonom dan merupakan ciri khas peradaban Yunani kuno. Demokrasi nampak pada polis Athena satu dari 
banyak polis di Yunani yang kerap dianggap sebagai pusat keilmuan. ${ }^{1}$ Sistem pemerintahan yang berlaku di polis Athena didasarkan pada suara mayoritas dalam pemungutan suara. Setiap permasalahan yang menyangkut kehidupan berpolis yang berkaitan dengan kepentingan publik diselesaikan dengan pemungutan suara. Sistem tersebut sayangnya lalu terkubur bersama peradaban Yunani kuno yang mulai surut. ${ }^{2}$ Yunani kehilangan pesonanya sebagai pusat peradaban dunia. Tidak lama setelah runtuhnya peradaban Yunani kuno Eropa masuk ke masa yang berat dan panjang.

Lama demokrasi terkubur tapi ia kembali mendapatkan nafasnya bersama lahirnya zaman baru di Eropa. Reinesance sebuah penemuan kembali, kelahiran yang baru, penggalian kembali warisan Yunani. Pada masa inilah sejumlah karya filsuf Yunani kuno untuk pertama kali mendapat perhatian serius di benua Eropa. Demikian pula demokrasi Yunani menjadi ilham bagi sekian filsuf dan pemikir. Bertitik tolak pada warisan Yunani dan pergumulan mereka dengan realitas zaman di mana mereka hidup demokrasi berkembang lebih lanjut. Kita mengenal namanama besar seperti John Locke, Rossoe dan Montesqeu. ${ }^{3}$ Mereka memberikan sumbangsih besar bagi perkembangan teori demokrasi yang kemudian banyak diadopsi negara modern. Namun kita tidak akan membahas secara terperinci pemikiran mereka. Sampai di sini saya tidak akan memperpanjang lagi tentang

\footnotetext{
${ }^{1}$ Wasino, Demokrasi, Dulu, Kini, dan Esok, Makalah Diskusi disampaikan dalam Diskusi Sejarah "Wajah Demokrasi Indonesia, Semarang 30-31 Maret 2009.

${ }^{2}$ Fuad Hasan, Bab Pengantar, dalam Plato, Apologia: Pidato Socrates yang Diabadikan Plato, (Jakarta: Bulan-Bintang, 1986), hlm. 29-31.

${ }^{3}$ Simon Petrus L. Tjahjadi, Petualanangan Intelektual, (Yogyakarta: Kanisius, 2014), hlm. 271277.
} 
perkembangan demokrasi di Eropa terutama secara teoritis karena memang bukan itu tujuan kita.

\section{B. Indonesia dan Ide Demokrasi}

Pemikiran tentang demokrasi dan penerapannya semakin menemukan bentuknya yang makin sempurna di negara-negara Eropa pada akhir abad 19 sampai awal abad 20. Namun di sisi lain kita tidak boleh lupa bahwa Eropa di tempat lain di tanah koloni dan jajahan justru menunjukkan wajah yang berbeda. ${ }^{4}$ Perkembangan demokrasi di Eropa sekali-kali tak ingin dibaginya kepada tanah jajahan. Meski berusaha sekuat tenaga memonopoli pencapaiannya dalam hal demokrasi nyatanya pemikiran tentang demokrasi bocor juga. Pada kasus Indonesia kita akan melihat bahwa kebocoran itu terutama sekali dimotori oleh sekolompok mahasiswa Indonesia yang dengan susah payah dan luar biasa mendapat akses untuk melanjutkan pendidikan di Eropa.

Kelompok mahasiswa ini mereka banyak berkenalan dengan ide-ide yang luhur yang agung dan memukau. Lebih jauh lagi mereka juga menjadi saksi kehidupan bernegara yang jauh lebih baik, lebih demokratis. Pengalaman tersebut sangat kontras dengan apa yang terjadi di tanah kelahiran mereka. Padahal bangsabangsa Eropa itulah yang sebenarnya sekarang berkuasa di tanah kelahiran mereka. Satu contoh konkret adalah apa yang dialami oleh Mohammad Hatta. Dia mengalami sendiri betapa bedanya kehidupan bernegara antara di negeri merdeka dan negeri terjajah.

\footnotetext{
${ }^{4}$ Werthreim W.F, Masyarakat Indonesia dalam Transisi: Studi Perubahan Sosial, terjemahan Misbah Zulfa Ellisabet, (Yogyakarta: Tiara Wacana, 1999), hlm. 51-52.
} 
Hatta di Belanda walaupun sebagai seorang dari tanah jajahan masih mendapat hak untuk membela diri di pengadilan. Pembelaannya yang terkenal diberi judul yang cukup berani, "Indonesia Vrij" ${ }^{56}$ Namun ketika Hatta kembali ke tanah air ternyata dia merasa tidak diperlakukan secara layak menurut hukum yang adil. Hatta ditangkap lalu diasingkan tanpa suatu proses pengadilan. ${ }^{7}$ Jika seorang Mohammad Hatta yang cerdas, terdidik, dan melek hukum dapat diperlakukan seperti itu lalu bagaimana dengan rakyat kebanyakan yang buta huruf ?

Pada generasi Hatta ide demokrasi terus meresap dalam gerakan menuntut kemerdekaan. Ide demokrasi yang 'dicuri dari negeri penjajah" menjalin pergumulan dengan kondisi real Indonesai dan konsep-konsep khas Indonesia. Kita akan menyaksikan pergumulan itu terus berlanjut di alam Indonesai merdeka walau mengalami jalan yang seringkali terjal dan berliku.

\section{Percobaan Awal}

Kekalahan Jepang pada perang dunia II dimanfaatkan Indonesia untuk memproklamirkan kemerdekaannya. Sebuah negara baru telah lahir dan demokrasi yang lama diidamkan mendapat jalannya. Indonesia lalu bergumul dengan percobaan-percobaan, hubungan dialektis yang komplek antara ide demokrasi, kondisi real bahkan kenyataan kembali Belanda yang masih berhasrat untuk menggenggam bekas negeri jajahannya. Menarik dan barangkali juga merupakan sebuah keberuntungan bahwa sejak awal kelahirannya Indonesia

\footnotetext{
${ }^{5}$ Mohammad Hatta, Untuk Negeriku Bukittinggi-Rotterdam Lewat Betawi Sebuah Otobiografi, (Jakarta: Kompas, 2011), hlm. 290.

${ }^{6}$ Ibid., hlm. 298-299.

${ }^{7}$ Ibid., hlm. 136-138.
} 
membuka diri terhadap demokrasi, Tidak ada penolakan tajam dari para founding father padahal mereka berasal dari latar belakang yang sangat beragam.

Kalangan Islam bahkan yang berasal dari tradisi santri yang kental tidak menampilkan penolakan yang keras. Padahal di tempat lain seringkali Islam dan demokrasi tak bisa didamaikan. ${ }^{8}$ Secara cukup berani di usianya yang masih muda Indonesia mencoba mengadopsi sistem demokrasi parlementer. Kabinet bertanggungjawab terhadap parlemen yang dibentuk bukan melalui pemilu. Keadaan masih terlalu gawat untuk melaksanakan pemilu nasional. Indonesia nampaknya masih dipenuhi semangat sebagai bangsa yang baru mendapatkan kemerdekaannya. ${ }^{9}$ Percobaan tersebut nyatanya tidak mudah. Keadaan terlalu komplek dan berat, pertentangan intern, kondisi infrastruktur dan suprastruktur, rakyat nyaris tidak punya pengalaman politik yang matang masih harus ditambah usaha bertahan menghadapi Belanda.

Demokrasi parlementer berjalan terseok-seok. Kabinet jatuh bangun dengan cepat sebelum berbuat banyak. Kabinet seringkali tak berdaya sampai presiden dan wakil presiden harus turun tangan, pasang badan untuk menolong kabinet dari serangan parlemen. ${ }^{10}$ Meski berat Indonesia akhirnya mampu melewati masa sulit. Belanda bersedia memberikan pengakuan terhadap Indonesia. Suatu penyerahan kedaulatan yang tentu saja tidak dengan gratis dan ikhlas. Namun setidaknya Indonesia menjadi punya lebih banyak waktu untuk menata dirinya. Tahun 1950 dibuat suatu Undang-Undang Dasar Sementara untuk menyokong sistem

\footnotetext{
${ }^{8}$ Ahmad Syafii Maarif, Islam dalam Bingkai Keindonesiaan dan Kemanusiaan, (Bandung: Mizan, 2009), hlm. 161.

${ }^{9}$ Mohammad Hatta, Demokrasi Kita, dalam Joko S. Kahar dan Adib Susila, Pokok-Pokok Pikiran Bung Hatta, (Yogyakarta: Buku Litera, 2012), hlm. 111.

${ }^{10}$ Ibid.
} 
parlementer yang telah berjalan. Patut diingat bahwa sebenarnya Undang-Undang Dasar yang disusun tahun 1945 tidak memadai untuk sebuah republik parlementer.

Indonesia memasuki babak baru yang seringkali disebut masa Demokrasi Parlementer. Pada masa ini nyatanya jatuh bangun kabinet masih saja terjadi. Tidak ada kabinet yang mampu bertahan sampai dua tahun. Namun ada juga capaian yang patut dibanggakan yaitu pemilu tahun 1955. Sebuah pemilu yang dikenang sebagai salah satu pemilu paling demokratis sepanjang sejarah Indonesia. Setelah pemilu itulah parlemen yang sebenarnya baru terbentuk. Parlemen hasil pemilu ini ternyata juga cukup beragam dan seringkali terjadi pertentangan yang keras. Kabinet-kabinet masih juga tidak berusia panjang. ${ }^{11}$ Menurut Hatta kemelut ini dipicu oleh hasrat "berbagi rezeki" dan mengutamakan golongan sendiri. Golongan, partai, telah jatuh sebagai tujuan bukan kendaraan atau alat untuk melangsungkan kehidupan bernegara demi tercapainya tujuan negara. ${ }^{12}$ Sementara itu UUD 1950 yang bersifat sementara nyatanya berlangsung hampir selama sepuluh tahun. Konstituante sebagai badan yang dibentuk berdasarkan kekuatan partai hasil pemilu untuk menyusun undang-unadng dasar yang baru tak kunjung menyelesaikan tugasnya.

Militer yang sejak awal tidak menyukai demokrasi parlementer mulai tidak sabar dan mereka mendesak presiden untuk segera mengakhirinya. 17 Oktober 1952 Meriam-meriam di arahkan ke istana namun pemerintah masih bisa

\footnotetext{
${ }^{11}$ Vicker Adrian, Sejarah Indonesia Modern, (Yogyakarta: Insan Madani, 2011), hlm. 188-189

${ }^{12}$ Mohammad Hatta, op.cit., hlm. 115.
} 
mengatasi keadaan. ${ }^{13}$ Sukarno jelas terlalu kuat, terlalu populer untuk dilawan secara terbuka. Demokrasi parlementer jalan terus tetapi Sukarno sendiri kurang sepakat dengan sitem tersebut dan mulai mencari konsepsi baru. Konsepsi baru tersebut mulai nampak samar tahun 1957. Tahun 1959 Sukarno merasa waktunya sudah tepat dan konsepsinya telah mendapatkan bentuknya yang matang. Dimulailah apa disebut Sukarno sebagai penemuan kembali jalan revolusi Indonesia yang akan berjalan di bawah panji demokrasi terpimpin.

\section{Dua Konsepsi dari Dwitunggal yang Telah Tanggal}

Demokrasi terpimpin bagi Sukarno adalah suatu demokrasi khas Indonesia yang jauh lebih baik dan lebih tepat untuk diterapkan. Sukarno mengasalkan konsepsinya pada tradisi yang telah berkembang lama di desa-desa jauh sebelum Indonesia merdeka. Suatu demokrasi yang dipimpin, dibimbing oleh seorang tetua yang bersifat kebapakan. Suatu cara yang lebih baik di mana tidak akan ada saling sikut, pertentangan keras yang tak terdamaikan karena adanya sang pemimpin yang mampu menengahi. Pemimpin yang akan menggodok segala macam bahan dari pihak-pihak yang berlainan pendapat menjadi suatu masakan yang padu dan lezat. Sukarno memulai demokrasi terpimpin dan mengakhiri demokrasi parlementer dengan dekrit 5 Juli $1959^{14}$ Lebih jauh lagi tidak lama kemudian presiden membubarkan Dewan Perwakilan Rakyat yang terbentuk berdasarkan

\footnotetext{
${ }^{13}$ Adams Cindy, Bung Karno Penyambung Lidah Rakyat, terjemahan Abdur Bar Salim, (Jakarta: Gunung Agung, 1984), hlm. 405-406

${ }^{14}$ Ibid., hlm. 423-424
} 
pemilu 1955 karena perselisihan soal anggaran negara. ${ }^{15}$ Tindakan Sukarno jelas ditentang banyak pihak tetapi dekrit presiden jalan terus terutama karena didukung penuh oleh militer. Militer dengan senang hati mendukung keputusan presiden karena mereka memang telah lama muak dengan sistem parlementer.

Tentangan yang cukup lantang terhadap konsepsi demokrasi terpimpin justru datang dari mantan orang ke-dua di Indonesia. Hatta yang telah menarik diri karena perbedaan pandangan yang tak terdaimakan dengan Sukarno muncul sebagai kritikus yang tajam. Hatta melontarkan kritik sekaligus tawaran konsepsinya dalam tulisan yang berjudul "Demokrasi Kita". Tulisan tersebut dimuat dalam majalah Pandji Masyarakat yang diasuh oleh tokoh muslim ternama Hamka. ${ }^{16}$ Mereka berdua, Hatta dan Sukarno yang dalam masa-masa sebelumnya masih bisa berkompromi, bahu membahu membangun bangsa kini telah sepenuhnya bercerai. Kita melihat bahwa pertentangan antara Sukarno dengan Hatta benar-benar telah mencapai puncaknya. Dwitunggal telah berubah menjadi dwitanggal

Hatta dengan keras mengkritik Sukarno yang dikatakannya telah jatuh ke dalam kediktatoran. Demokrasi terpimpin bagi Hatta tidak akan bertahan lebih lama dari usia Sukarno sendiri. Konsepsi yang dibangun Sukarno mensyaratkan seorang pemimpin yang kuat. Padahal selain Sukarno tidak ada orang yang mampu berada di posisi pemimpin. Tidak ada orang yang punya kapasitas sekaliber Sukarno. Apa jadinya jika sewaktu-waktu Sukarno berhalangan tetap

\footnotetext{
${ }^{15}$ Mohammad Hatta, op.cit., hlm. 108

${ }^{16}$ Hamka, (1966), Pengantar, dalam S. Kahar dan Adib Susila, Pokok-Pokok Pikiran Bung Hatta, (Yogyakarta: Buku Litera, 2012), hlm. 106
} 
dan harus digantikan secara penuh. ${ }^{17}$ Sukarno telah menempatkan Indonesia dalam krisis demokrasi. Memang benar percobaan demokrasi parlementer kurang memuaskan tapi bukan berarti lalu demokrasi boleh dikebiri. Hatta menginsyafi bahwa sudah menjadi hukum besi, hukum sejarah jika demokrasi telah mengarah pada baku hantam, ego pribadi dan kelompok bahkan anarki maka akan lahir kediktatoran. Namun Hatta tetap optimis bahwa surutnya demokrasi hanya sementara karena baginya "lenyapnya demokrasi berarti lenyapnya Indonesia merdeka". ${ }^{18}$ Demokrasi harus terus ditumbuhkan justru karena itu lalu Hatta mengutarakan konsepsinya.

Menarik bahwa Hatta sebagaimana Sukarno juga mengambil contoh dari pelaksanaan demokrasi di desa-desa. Baik Sukarno maupun Hatta sama-sama meyakini bahwa demokrasi telah menjadi bagian tak terpisahkan dari kehidupan bangsa Indonesia. Namun kita akan melihat bahwa konsepsi yang mereka bangun justru bertolak belakang. Sukarno lebih menekankan pada keberadaan sang pemimpin, sang tetua, atau sang kepala desa sementara Hatta lebih menekankan pada proses mufakat melalui proses rapat tanpa ada penonjolan yang berlebih terhadap satu individu entah dia kepala desa atau apa pun namanya. ${ }^{19}$ Hatta dalam membangun konsepsinya bergerak lebih jauh daripada Sukarno. Hatta juga mengambil inspirasi dari demokrasi di Eropa. Hatta menyinggung konsep Rousseau dan revolusi Perancis. Namun Hatta mengkritik keduanya karena jatuh dalam individualisme dan menyebabkan tumbuh suburnya kapitalisme.

\footnotetext{
${ }^{17}$ Mohammad Hatta, op.cit., hlm. 118

${ }^{18}$ Ibid., hlm 128.

${ }^{19}$ Ibid., hlm. 124-125.
} 
Demokrasi model demikian bagi Hatta pada akhirnya hanya menguntungkan sebagian pihak yaitu kaum kapitalis dan menindas kelompok yang lain. Demokrasi Indonesia tidak boleh jatuh pada keadaan seperti itu.

Bagi Hatta demokrasi Indonesia haruslah suatu demokrasi yang bersifat Demokrasi-Sosial. Demokrasi di bidang politik saja tidak cukup tetapi juga harus dibarengi dengan demokrasi di bidang ekonomi. Demokrasi yang demikianlah yang cocok dengan cita-cita bangsa Indonesia untuk terciptanya suatu tatanan masyarakat berkeadilan sosial, keadilan yang meliputi seluruh aspek kehidupan. Hatta lebih jauh menerengkan bahwa konsep demokrasi sosial ala Indonesia berasal dari tiga sumber. Ketiga sumber tersebut yaitu paham sosialis barat, ajaran Islam, dan masyarakat Indonesia yang berdasarkan kolektivisme. Demokrasi yang demikian bagi Hatta hanya mampu berjalan dengan syarat tertentu. Syarat tersebut menurut Hatta yaitu, “....adanya kesadaran akan tanggungjawab dan toleransi serta kesediaan hati untuk melaksanakan prinsip the right man in the right place orang yang tepat pada tempat yang tepat". ${ }^{20}$ Hatta dalam konsepsinya mampu menunjukkan kapasitas sebagai seorang pemikir. Dia tidak hanya mengekor pendapat atau konsepsi yang sudah ada tapi juga mengkritik dan membangun konsepsinya sendiri. Suatu upaya yang kental dengan tradisi berpikir di dunia barat.

Memasuki tahun 1965 ramalan Hatta makin nampak menuju kenyataan. Kubu-kubu kekuatan utama yang selama ini mampu berjalan seiring karena dipimpin Sukarno kian mengerucut pada pertentangan tak terdamaikan. Mereka mulai sangsi pada fungsi Sukarno sebagai penyeimbang. Dua kutub utama yang

\footnotetext{
${ }^{20}$ Ibid., hlm. 132
} 
nampak kian tak terdaiamakan adalah PKI dan satu sayap dalam tubuh militer. Keduanya mulai membayangkan suatu keadaan tanpa Sukarno. Pertentangan tersebut akhirnya melahirkan satu pantikan keras, menyulut sumbu ledakan beruntun yang mendongkel Sukarno dan merobohkan seluruh bangunan konsepsinya. ${ }^{21}$ Pada titik ini kritik dan prediksi Hatta bisa dikatakan sangat tepat. Namun apakah selama pelaksanaannya konsepsi demokrasi terpimpin Sukarno memang sepenuhnya berjalan sebagaimana yang diharapkankan Sukarno sendiri. Apakah Sukarno benar-benar sempat menumpuk kekuasaan di tangannya dan menjadi seorang diktator. Banyak pihak berpendapat ya bahwa Sukarno telah sempat menjadi seorang diktator yang menumpuk kekuasaan di tangannya.

Saya sendiri cenderung untuk lebih mengikuti pandangan Daniel Lev $^{22}$ dan Pramoedya Ananta Toer. ${ }^{23}$ Menurut Daniel Lev sebenarnya Sukarno hampir tidak punya kekuasaan real. Sukarno hampir selalu dalam keadaan terdesak. Militerlah yang lebih banyak mengambil inisitaif. Memang benar dia mampu mengumpulkan massa lalu secara memukau mengutarakan konsepsinya dan nyaris tidak ada yang mampu melakukan oposisi terbuka terhadap konsepsi Sukarno. Namun apakah di luar itu Sukarno punya kekuasaan. Pram lebih jauh menegaskan bahwa di luar hal tersebut milierlah yang lebih berkuasa. Militer seringkali bergerak bahkan melakukan penangkapan, penahanan paksa, tanpa

\footnotetext{
21 John Rossa, Dalih Pembunuhan Massal: Gerakan 30 September dan Kudeta Soeharto, terjemhan Hensri Setiawan, (Jakarta: Hasta Mitra, 2008), hlm. 294-300.

${ }^{22}$ Daniel S Lev, Ketika Politik Turun ke Jalan, wawancara, dalam http://www.oocities.org/forumleuven/artikel/daniel2.html diakses 21 September 2013 pukul 13.13 .

${ }^{23}$ Pramoedya Ananta Toer, wawancara, dalam, August Hans den Boef dan Kees Snoek, Saya Ingin Lihat Semua Ini Berakhir; Esai dan Wawancara dengan Pramoedya Ananta Toer, (Jakarta: Komunitas Bambu, 2008), hlm. 136-137.
} 
seizin dan sepengetahun Sukarno. Pram sendiri pernah menjadi korban penangkapan dan penahanan tanpa tuduhan dan proses peradilan yang menurutnya terjadi diluar kuasa Sukarno.

\section{E. Demokrasi Pancasila Gaya Orba}

Robohnya demokrasi terpimpin sempat membawa harapan baru, kehidupan demokrasi yang lebih baik. Banyak pihak termasuk kalangan intelektual dan mahasiswa menaruh harapan pada aktor baru yang kemudian menyebut dirinya sebagai "Orde Baru" untuk membedakan diri dengan demokrasi terpimpinnya Sukarno yang kemudian populer disebut "Orde Lama". Mahasiswa dengan bersemangat ikut merobohkan sisa-sisa bangunan konsepsi Sukarno. Bahkan Hatta sendiri awalnya juga menaruh harapan terhadap orde baru. ${ }^{24}$ Pertemanpertemuan diadakan untuk membahas konsep baru, konsep angkatan 66 untuk membangun orde baru. Orde baru berusaha menunjukkan diri secara meyakinkan sebagai penyelamat dan pembela Pancasila dan UUD 1945 yang murni. Mereka lahir karena "orde lama" telah terlalu jauh menyimpang dari Pancasila dan UUD 1945 yang murni. Begitu pula soal demokrasi. Demokrasi haruslah dibangun berdasarkan kaidah-kaidah dalam Pancasila dan UUD 1945. Malahan setiap usaha untuk berpaling atau menggeser Pancasila dan UUD 1945 harus diminimalisir sedini mungkin sekalipun harus dengan memanipulasi parlemen. ${ }^{25}$ Sekilas konsepsi baru ini nampak indah dan menggembirakan, sesuai dengan demokrasi

\footnotetext{
${ }^{24}$ Deliar Noer, Mohammad Hatta Hati Nurani Bangsa, (Jakarta: Kompas, 2012), hlm., 163-165.

${ }^{25}$ Nugroho Noto Susanto, ed., Tercapainya Konsensus Nasional, (Jakarta: Balai Pustaka, 1985), hlm. 49 .
} 
ala Indonesia yang diharapkan oleh Hatta. Namun harapan itu kian memudar. Orde baru dengan segera tumbuh sebagai penafsir tunggal atas Pancasila dan UUD 1945.

Orde baru mulai tumbuh sebagai kekuatan yang ingin mengontrol segala hal bahkan soal ingatan dan tafsir Pancasila. Kenyataannya setiap kebijakan orde baru terutama upayanya membangun demokrasi Pancasila jatuh pada sikap otoriter yang sebenarnya. Demokrasi Pancasila hanya suatu pulasan tipis untuk pertumbuhan suatu demokrasi yang sebenarnya demi kepentingan kelompok penguasa. Demokrasi parodi di tengah panggung politik, parlemen lumpuh dan tinggal jadi kumpulan yes man, pemilu bahkan sudah diketahui hasilnya sebelum dimulai. Rakyat dijauhkan dari politik, dari proses berdemokrasi yang sebenarnya atas nama hal-hal seperti stabilitas, keamanan, dan pertumbuhan ekonomi. Soeharto sebagai pemimpin orde baru semakin mengokohkan dirinya sebagai pemimpin tunggal. ${ }^{26}$ Anehnya dunia barat yang terkenal demokratis itu sama sekali tak mempermasalahkan berbagai tindakan Soeharto yang kontroversial dan membiarkannya memegang tampuk kekuasaan selama 32 tahun. Semua itu mendapat restu dan disambut gembira oleh kubu negara demokratis, pembela dunia bebas (free word) yang dipimpin Amerika Serikat. ${ }^{27}$ Tidakkah polanya terlalu mirip dengan gaya yang pernah dipraktekkan pemerintah Belanda yang telah disinggung pada awal tulisan ini ? Tidakkah ini bisa dikatakan perkembangan lebih lanjut dari gaya kolonialisme yang pernah kita alami pada

\footnotetext{
26 Jenkins David, Soeharto dan Barisan Jenderal Orba, terjemahan Harsutedjo, (Jakarta: Komunitas Bambu, 2010), hlm. 17.

${ }^{27}$ Lihat C. Korten David, The Post-Corporate World: Kehidupan Setelah Kapitalisme, terjemahan A. Rahman Zainuddin, (Jakarta: Obor, 2002). Lihat juga Perkins John, Pengakuan Seorang Ekonom Perusak, terjemahan Herman Tirtaatmaja dan Dwi Karyani, (Jakarta: Abdi Tandur, 2004).
} 
masa-masa yang telah lalu? Suatu pola yang dengan keras diprotes Sukarno dan disampaikannya secara terbuka dalam pidato di $\mathrm{PBB} .^{28}$

\section{F. Tantangan dan Harapan Baru}

Setelah bertahan cukup lama orde baru akhirnya kehilangan pesonanya. Penguasa tak lagi mendapat kepercayaan dari mayoritas rakyat. Tekanan krisis ekonomi, bencana, alam dan berbagai gerakan yang terutama dimotori mahasiswa dan berbagai faktor lain akhirnya berhasil merobohkan Soeharto. Reformasi menjadi trend banyak pejabat dan tokoh terkenal berlomba-lomba mengaku reformis sebagaimana dulu mereka berlomba-lomba mengaku Pancasilais. Harapan baru berhembus. Kebebasan mulai terbuka dan demokrasi seolah mulai kembali mendapatkan nafasnya. Pemilu pertama pasca orde baru diikuti banyak sekali partai yang seringkali membuat rakyat kebanyakan bingung.

Sampai hari ini demokrasi politik prosedural berkembang dengan sangat pesat. Secara prosedur demokrasi di Indonesia telah bergerak ke arah yang demokrasi liberal. Serentak dengan semakin liberalnya demokrasi Indonesia demikian juga sistem ekonominya. Negara ini terus-menerus maju (atau didorong dengan paksa) menjadi negara pasar terbuka. Seorang Indonesianis terkemuka William Lidle berpendapat bahwa memang antara demokrasi dan kapitalisme pasar tidak bisa dipisahkan seperti bayi dengan bak mandinya. Liddle yakin bahwa demokrasi hanya bisa mendapatkan tempatnya di negara yang menerapkan ekonomi

\footnotetext{
${ }^{28}$ Sukarno, Membangun Dunia Kembali, pidato di PBB tanggal 30 September 1960, dalam penasoekarno.worpress.com diakses 10 Oktober 2015 pukul 19.00 wib.
} 
kapitalisme pasar. ${ }^{29}$ Memang sejak berakhirnya perang dingin seolah sistem politik demokrasi dan sistem ekonomi kapitalisme pasar ala Amerika Serikat telah menjadi pemenang mutlak. Alternatif gaya yang lain terutama varian kiri (komunisme, sosilaime dan segala percabangannya) seolah kehilangan pesona dan daya hidupnya.

Meski demikian tidak sulit bagi kita untuk melihat bahwa ternyata buah dari demokrasi kita hari ini masih penuh lubang. Apalagi jika yang dibicarakan adalah pemilu. Pemilu kita nyatanya belum mampu memunculkan orang-orang terbaik dan menempatkannya di tempat yang tepat. Banyak pejabat hasil pemilu ternyata jatuh dalam kasus korupsi, kolusi, dan nepotisme. Tidak bisa dipungkiri salah satu sebab terbesarnya adalah mahalnya biaya demokrasi. Mendaftar untuk dapat dipilih dalam pemilu mungkin saja memang gratis tetapi biaya kampanye, bahkan pembentukan citra demi meraih simpati rakyat yang akan mengantarkan perolehan suara maksimal seringkali harus dibayar mahal. ${ }^{30}$ Akibatnya kesenjangan malah kian parah karena mereka yang terpilih seringkali mengutamakan balik modal, bahkan membangun suatu lingkar kekuasaan dengan menarik para kerabat dan kolega demi langgengnya kekuasaan. Sementara itu di sisi lain negeri ini diminta untuk terus membuka diri, bertranfosmasi menjadi ladang kapitalisme pasar. Privatisasi, deregulasi, dan pengurangan subsidi atas nama efisiensi dan persaingan sehat gencar dianjurkan terutama oleh negara kaya melalui lembaga donor. Pengelolaan negara dan sumber daya alam bahkan yang menyangkut hajat

\footnotetext{
${ }^{29}$ Liddle R. William dkk., Memperbaiki Mutu Demokrasi di Indonesia, (Jakarta: PUSAD, 2012), hlm. 8-9.

${ }^{30}$ Yudhi Latif, Revolusi Pancasila, dalam kompas.com, diakses 30 September 2015, pukul 17.00 wib.
} 
hidup rakyat banyak kian jatuh ke pihak swasta yang seringkali merupakan swasta asing.

Lalu harus bagaimana kita membenahi demokrasi kita? Tepat disinilah saya merasa pemikiran Hatta dalam "Demokrasi Kita" layak untuk kembali diangkat. Pemikiran Hatta akan menuntun kita membangun demokrasi yang lebih baik. Demokrasi Pancasila dalam tafsiran baru guna menapaki tantangan zaman yang terus berubah.

\section{G. Penutup}

Demokrasi merupakan warisan peradaban Yunani kuno yang mengilhami banyak negara untuk menata kehidupannya. Sampai hari ini demokrasi diterima luas sebagai model yang paling baik tak terkecuali di Indonesia. Sejarah telah menunjukkan bahwa demokrasi di Indonesia tidak selalu berjalan mulus. Demokrasi sebagai ide yang dicuri dari negeri penjajah telah bergumul dengan realitas kehidupan dan berbagai konsepsi yang dikatakan khas Indonesia. Demokrasi mengalami pasang surut bahkan pernah mencapai pada titik kritis.

Para elit politik dan aktor demokrasi di negeri ini tidak jarang mampu membangun konsep demokrasi yang baik. Sayangnya ada dua kelemahan mendasar yang seringkali melanda negeri ini. Pertama konsepsi demokrasi yang dibangun oleh elit kemudian seringkali jatuh pada tafsir tunggal yang dipaksakan. Kedua konsespsi yang telah dibangun seringkali tidak diiringi komitmen penuh untuk melaksanakannya. Akibatnya konsep tinggal jadi konsep dan demokrasi negeri ini terombang-ambing tanpa rel yang jelas. Belajar dari kenyataan itulah 
untuk menata kehidupan bernegara dan menatap masa depan yang lebih cerah alangkah baiknya kita kembali ke demokrasi Pancasila.

Kita tidak boleh lagi-lagi jatuh pada kesalahan yang serupa. Demokrasi Pancasila hendaknya dibangun melalui diskusi yang berkelanjutan tanpa pemaksaan kehendak oleh golongan manapun. Kita juga harus belajar untuk berkomitmen terhadap konsespsi yang kita bangun. Hanya dengan demikian akan tercipta konsepsi yang bermakna dan mencapai kepenuhannya dalam rangka membangun kehidupan berdemokrasi yang lebih baik.

\section{Daftar Pustaka}

Adams Cindy, Bung Karno Penyambung Lidah Rakyat, terjemahan Abdur Bar Salim, (Jakarta: Gunung Agung, 1984).

Ahmad Syafii Maarif, Islam dalam Bingkai Keindonesiaan dan Kemanusiaan, (Bandung: Mizan, 2009).

August Hans den Boef dan Kees Snoek, Saya Ingin Lihat Semua Ini Berakhir; Esai dan Wawancara dengan Pramoedya Ananta Toer, (Jakarta: Komunitas Bambu, 2008).

C. Korten David, The Post-Corporate World: Kehidupan Setelah Kapitalisme, terjemahan A. Rahman Zainuddin, (Jakarta: Obor, 2002).

Deliar Noer, Mohammad Hatta Hati Nurani Bangsa, (Jakarta: Kompas, 2012).

Jenkins David, Soeharto dan Barisan Jenderal Orba, terjemahan Harsutedjo, (Jakarta: Komunitas Bambu, 2010).

John Rossa, Dalih Pembunuhan Massal: Gerakan 30 September dan Kudeta Soeharto, terjemhan Hensri Setiawan, (Jakarta: Hasta Mitra, 2008).

Liddle R. William dkk., Memperbaiki Mutu Demokrasi di Indonesia, (Jakarta: PUSAD, 2012).

Mohammad Hatta, Untuk Negeriku Berjuang dan Dibuang Sebuah Otobiografi, (Jakarta: Kompas, 2011). 
Otobiografi, (Jakarta: Kompas, 2011).

Nugroho Noto Susanto, ed., Tercapainya Konsensus Nasional, (Jakarta: Balai Pustaka, 1985).

Perkins John, Pengakuan Seorang Ekonom Perusak, terjemahan Herman

Tirtaatmaja dan Dwi Karyani, (Jakarta: Abdi Tandur, 2004).

Plato, Apologia: Pidato Socrates yang Diabadikan Plato. (Jakarta: BulanBintang, 1986).

S. Kahar dan Adib Susila, Pokok-Pokok Pikiran Bung Hatta, (Yogyakarta: Buku Litera, 2012).

Simon Petrus L. Tjahjadi, Petualanangan Intelektual, (Yogyakarta: Kanisius, 2014)

Vicker Adrian, Sejarah Indonesia Modern, (Yogyakarta: Insan Madani, 2011).

Werthreim W.F., Masyarakat Indonesia dalam Transisi: Studi Perubahan Sosial, terjemahan Misbah Zulfa Ellisabet, (Yogyakarta: Tiara Wacana, 1999).

Internet:

Daniel S Lev, Ketika Politik Turun ke Jalan, wawancara, dalam http://www.oocities.org/forumleuven/artikel/daniel2.html diakses 21 September 2013 pukul 13.13.

Sukarno, Membangun Dunia Kembali, pidato di PBB tanggal 30 September 1960, dalam penasoekarno.worpress.com diakses 10 Oktober 2015 pukul 19.00 wib.

Wasino, Demokrasi, Dulu, Kini, dan Esok, Makalah Diskusi disampaikan dalam Diskusi Sejarah “Wajah Demokrasi Indonesia, Semarang 30-31 Maret 2009.

Yudhi Latif, Revolusi Pancasila, dalam kompas.com, diakses 30 September 2015, pukul 17.00 wib. 